\title{
AZ ÚTIKÖNYVEK TÍPUSAI ÉS XXI. SZÁZADI LEHETŐSÉGEI
}

\author{
Elekes Tibor
}

\section{Összefoglalás}

A 20. század elejére kialakult az útikönyvek feladatához igazodó általános felépítés és tartalom. A történelmi korszakok ideológiai hatásai szöveges tartalmakban, fényképekben jelennek meg a kiadványokban. Multikulturális területeken az olvasók elvárásainak megfelelően hangsúlyosabb a saját kultúrához kapcsolódó elemek és információk bemutatása. Az útikönyvsorozatok jellegzetes kiadói funkciókkal jelennek meg. A nyomdatechnika, a fényképezés és a térképszerkesztés fejlesztése nyomon követhető a kiadványok minőségének változásában. A technikai fejlődés javította az útikalauzok minőségét és megjelenítését, a későbbi technikai lehetőségek és az internet azonban versenytárssá váltak számukra. Manapság az útikönyvek kiegészítik az IKTés a technikai lehetőségeket, és továbbra is bemutatják a desztinációkhoz kapcsolódó információk fö forrásait.

A 20. századi útikönyvek többnyire kulturális-tudományos értékeket közvetítenek, amelyek gyakorlati célokra orientálódtak. A 20. század végére egy újabb típusú útikalauz alakult ki, ahol kikapcsolódási és szórakoztató központú élményteremtési lehetőségek jelentek meg. A mai útikönyvek egyik feladata a piac igényeinek megfelelő egyensúly megtalálása, megvalósítása és közvetítése. Célszerű, ha egy ország, régió, város útikönyvét az adott ország vagy régió „anyanyelvi beszélője” írja. Ebben az esetben az olvasó megkapja az IKT-források által biztosított gyakorlati információk, tudományos és müvészeti ismeretek, valamint a személyes tapasztalatok szintézisét. Ez az olvasó-utazó személyesebb, élményalapú ismertetőt nyújt, amely színesebb, mint az általános.

Kulcsszavak: útikönyv, változatok, XX. század, lehetöségek, XXI. század eleje JEL: $Z 32$ 


\title{
TYPES OF TRAVEL GUIDEBOOKS AND THEIR OPPORTUNITIES IN THE 21ST CENTURY
}

\begin{abstract}
By the beginning of the 20th century the structure and the contents of the guidebooks adapted to their function were developed in our areas. The ideological influence of historical eras appeares in their textual contents, in photographs. In multicultural areas, according to the expectations of the readers, the presentation of elements and information related to their own culture is more pronounced. Series of guidebooks appear with distinctive publishing features. Improvements in printing technology, photography and map editing can be traced in the changes of the quality of publications Technical advances have improved the quality and display of travel guidebooks, and later technical capabilities and the Internet have become a competitor to them. Nowadays they supplement the ICT and technical possibilities and continue to present the sources of obtaining information and introducing destinations.

The guidebooks of the $20^{\text {th }}$ centuries conveying mostly cultural-scientific values which were oriented towards practical purposes. By the end of the $20^{\text {th }}$ century another type of travel guidebooks had developed, where recreation and entertainment-centered experience-making opportunities came into being.

One of the tasks of the today's guidebooks is to find, implement and mediate the right balance for the needs of the market. It's preferable that the guidebook of a country, region, city be written by a "native and native speaker" of the given country or region.

In this case the reader receives a synthesis of practical information, scientific and artistic knowledge provided by ICT sources as well as experiences based on personal experiences. This gives the reader-traveler a more personal aesthetic experience that is more colorful than the general one.
\end{abstract}

Keywords: travel guidebooks, versions, 20th century, opportunities, the beginning of the 21st century

JEL: $Z 32$ 


\section{Bevezetés}

Az utóbbi évtizedek egyik leggyorsabban fejlődő ágazata a turizmus. Az internet megjelenéséig elsődleges volt az útikönyvek és a turistatérképek jelentősége az információszerzésben, a desztinációk bemutatásában, ismertetésében (Markos-Kolacsek, 1961). A korábbi információhiányt a média közreműködésével online információözön váltotta fel. Desztinációk és turisztikai szolgáltatások naprakész szöveges és számszerű értékelései karnyújtásnyi közelségbe kerültek, igénybevehetővé váltak az utazó igényei és anyagi lehetőségeinek függvényében. A térbeli mobilitást a mobiltelefonok GPS-alapú applikációit használó navigációs szoftverek segítik (Michalkó et al., 2018). Az informatika, a technika fejlődése, az internetes lehetőségek az útikönyvek világát is átalakította. Az útikönyvek és a térképek továbbra is használatban vannak, kiegészítik az informatikai, technikai lehetőségeket, próbálnak igazodni a piaci igényekhez. A kérdés, hogy mennyire tölthetik be szerepüket az útikönyvek a 21. század elején? Miként egészíthetik ki, igazodnak a XX. század második felétől rohamosan fejlődő információtechnológia által felajánlott forrásokhoz, lehetőségekhez?

\section{Módszerek és felhasznált források}

Napjainkra a turizmus kialakulásával, fejlődésével, ágazataival, kutatásával kapcsolatos szakkönyvek egész sora jelent meg. A turizmusföldrajz szakirodalmát gazdagította Michalkó (2007), Gyuricza (2008), Nedelcu (2011), Gherghilas (2014), Mason (2017) tudományos tevékenysége. Az útikönyvek szerény irodalmához soroljuk De Beer (1952) és Lukács (2012) munkáját.

Jelen tanulmány elsősorban Erdélyt, Romániát az utóbbi két évszázadban bemutató útikönyvek példáján - a teljesség igénye nélkül - ismerteti e műfaj sajátosságait, változásait.

\section{Rövid történeti áttekintés}

A mai útikönyvek eredetének tekintett legrégebbi munkák Lukács (2012) összegzése szerint a Kr. e. VIII-VI. századi görög világig nyúlnak vissza, azok egy sziget, félsziget vagy az akkor ismert világ leírását tartalmazták (De Beer, 1952; Towner, 2000), később a római kori itineráriumok segítették a tervezett utazás előkészítését. Sztrabón (Kr. e. 63 körül - Kr. u. 23 után), ókori utazó, földrajzi író Geographica című munkájában korabeli természeti, helytörténeti, kultúrtörténeti, néprajzi adatokat örökített meg. A középkori Európa keresztény itineráriumai a kereskedők és a zarándokok 
számára nyújtottak hasznos információkat. Ismertették az útviszonyokat, a szálláslehetőségeket, a távolságokat, de helyszínekhez kötődő rövid történeteket, anekdotákat is (Ürögdi, 1979; Lukács, 2012). Charles Estiènne La Guide des Chemins de France, 1552-ben megjelent könyve közel 300 franciaországi útvonal gazdasági, politikai és turisztikai információit közli, műve útikönyvként értékelhető (Towner, 2000). Az 1770-es évekre, elsősorban a brit arisztokrácia körében elterjedtté vált európai körút (Grand Tour) útikönyvei tudományos és művészeti ismeretek előzetes elsajátítására ösztönözték az utazót (Gyömrei, 1934; Lukács, 2012).

A napoleoni háborúk után új lendületet kapott az arisztokrácia fiatal férfi tagjainak utazási kedve. Az első útikönyvek mintájának kialakítása John Murray III. kiadó nevéhez kapcsolódik, az első franciaországi és olaszországi útikalauzokat Mariana Starke írta. Már az 1824-ben megjelent munkájában a részletes úticélok mellett utazó családok számára is hasznos gyakorlati információkat közölt (útlevél, szállás, étkezés, egészségügyi problémák megoldási lehetőségei). Az ő nevéhez kapcsolódik a mai „csillagos látnivalók” rendszerének gondolata.

Korabeli jelentős európai útikönyvkiadó Karl Baedeker (Gyömrei, 1934; Buzzard, 2002; Lukács, 2012). Az 1850-es évektől, a történelmi Magyarország területén a kiegyezés után, az I. világháború kitöréséig terjedő fél évszázad a „polgári utazások" időszaka. Kedveltté váltak a hétvégi, a néhány napos, egy kisebb térséghez kapcsolódó utazások (Gyömrey, 1934; Lukács, 2012). Megjelentek a sajátos desztinációt, érdeklődési kört, korcsoportot célzó útikönyvek. Felértékelődött a természeti látványosságok szerepe.

1909-ben jelent meg Posewitz Tivadar A Szepesi középhegység „utazási kézikönyvének" 3. kiadása. Az átnézeti domborzati-vízrajzi és várostérképeket, valamint fényképeket tartalmazó zsebkönyv első fejezete a természeti adottságokat, történelmi, művelődési, népesedési adatokat és jelentős műemlékeket ismerteti. További tíz fejezet a terület desztinációit mutatja be részletesen, feltüntetve elérhetőségeket, magasságot, távolságot, „gyalog- illetve kocsin megtett időt”, belépti- és vezetődíjat. Képekkel illusztrált természeti, történelmi, művészeti értékeket ismertet. Nem tartalmaz szállással, étkezéssel kapcsolatos információkat, de szerepelnek az időjárást, közbiztonságot, helyi szokásokat bemutató gondolatok. Részben megfelel a mai útikönyvek által támasztott igényeknek.

\section{Eredmények}

A XX. század elején már sajátos, funkcióhoz igazodó szerkezet szerint készültek az útikönyvek. Nagyobbrészt ugyanezt a szerkezetet, formát, felépítést követték a későbbi időszakban, napjainkig megjelent munkák, de eltérő stílus-, tartalmi, minőségi 
változatokban. Az alábbiakban elemzett kiadványok összehasonlítása - a teljesség igénye nélkül - e változatosságot tárja föl.

A Les Guides Bleus sorozatban 1933-ban jelent meg a Roumanie, Bulgarie, Turquie útikönyv. Mérete, formája, szerkezete, tartalma alapján a korabeli útikönyv „klasszikus” példája. A francia utazóközönség számára készült. Az általános országismertetőt a közlekedési lehetőségeket tartalmazó útvonalak mentén elhelyezkedő jelentősebb városok, természeti látványosságok tömör ismertetése követi. A korabeli hivatalos forrásokat felhasználó munkában a kevés elírás, hiba a bemutatott területet kevésbé ismerő francia szerzők és szerkesztők rovására írható. A tájékozódást a nagyméretű, „kinyitható”, színes és az egy- vagy kétoldalas, jó minőségü térképek segítik. Terjedelmi okokra is visszavezethető a szállás- és étkezési lehetőségek, valamint a képek hiánya.

Ugyancsak 1933-ban jelent meg a Cluj-Kolozsvár kalauz. Amint a szerző, Orosz Ferenc írja az Előszóban, a Kelemen Lajos által írt Kolozsvári Kalauz 1902-es megjelenése óta eltelt időszak változásait, fejlődését próbálja megjeleníteni. Különös hangsúllyal ismerteti a város történelmi nevezetességeit, múzeumait. Az általános városképet a város története, majd az útvonalak mentén elhelyezkedő épületek, emlékművek fényképekkel illusztrált ismertetése követi a Séta a városban fejezetben. Müvelődéstörténeti értéket is képvisel a Betüsoros uccajegyzék, a város hivatalos román és korábbi magyar utcaneveinek táblázata. A könyv félnapos, illetve egy-két napos Kolozsvár környéki kiránduláslehetőségeket is bemutat. Az utolsó fejezet részlet- és átnézeti várostérképeket, valamint a térség turistatérképét tartalmazza. A szállás- és étkezési lehetőségek mellett az egészségügyi ellátás, az oktatás, az egyházak, a társadalmi, gazdasági élet szereplőinek címmel történő felsorolása is megtalálható a könyvben.

A II. világháborút követő román államhatalmi rendszerben a turizmus új fejlődési szakasza az 1960-as évektől kezdődött. Ekkor jelentek meg az új ideológiához igazodó, országot, megyét, várost vagy hegységet bemutató útikönyvek (Cioculescu, 1967; Murgu, 1967). A kor tudományos szintjéhez igazodó, igényes nyelvezetü munkákban teret kapott a hivatalos történelemszemléletet, a nemzeti és kommunista ideológiát propagáló szövegrészek, gyár- és tömbháznegyed-fényképek. Az egészségügyi intézmények, a szállás-, étkezési és szórakozási lehetőségek mellett - elsősorban a városkalauzokban - gyakran telefonos elérhetőséget is feltüntető, címmel ellátott felsorolásban szerepelnek az állami, a politikai, az oktatási és kulturális intézmények. A központosított állam elvárásaihoz igazodva Romániában nem jelentek meg történelmi régiókat bemutató útikalauzok, csak ország-, megye- vagy városkalauzok.

A magyarországi Panoráma kiadónál, az országokat bemutató sorozatban jelent meg a több kiadást megért Románia című útikönyv (Ádám et al., 1979). A mindenkori legbővebb, legszéleskörübb és legteljesebb Romániát bemutató, magyar nyelvű útikönyv (a természetleírás, a desztinációk bemutatásának jelentős része napjainkban is érvényes). Szerzői a korabeli tudományos, művelődési, művészeti világunk jeles 
képviselői. A földrajzi, történelmi, irodalmi-művelődési fejezetek után a részletes útikalauz rész földrajzi-történelmi régiók és útvonalak szerint ismerteti a desztinációkat. A román és magyar nevükkel szereplő városok földrajzi, népesedési, történelmi ismertetését a látványosságok szakszerü leírása követi. A településleírások szövegét kisebb betűs, részletes történelmi, művészeti, művelődéstörténeti, magyarázó, kiegészítő részek taglalják. Az ismertetések része a II. világháború után elért gazdasági eredmények, az ideológia megjelenítése. A könyv utolsó fejezeteinek témája az utazás, megközelítés, az idegenforgalmi szolgáltatások, a hasznos tanácsok és az útiszótár. A fekete-fehér képek a fejezetekhez illesztve 6-12 oldalas tömbökben, az út- és vasúthálózatot, valamint a sorszámozott és kétnyelvü névanyaggal ellátott, látványosságokat feltüntető várostérképek a könyv végén szerepelnek. A könyvborító belső oldalaira országtérképet helyeztek el. E sorozat útikönyvei elsősorban tudományos ismeretek, és a művészet segítségével ösztönzik az olvasót-utazót a kiválasztott desztináció megismerésére, megértésére, felfedezésére. A könyvben kevés a helyiek életmódját, szokásait bemutató gondolat. Az ismeretszerzés, -elmélyítés mellett adott az esztétikai élményszerzés lehetősége.

Eltérő formájú, de hasonló szerkezetű, felépítésü, stílusúak a Panoráma Kiadónál megjelent „Utazások...” sorozat történelmi, turisztikai régiókat ismertető munkái. A több kiadást megért Utazások Erdélyben (Mátyás, 1986) több életmódleírást, néprajzi értéket és kevesebb történelmi, földrajzi, gazdasági információt közvetít, mint a korábban ismertetett Románia-útikönyv. Az erőteljesebb mủvészeti, művelődéstörténeti jellegét hangsúlyozzák, de gyakorlatias jelleget is kölcsönöznek a sajátos térképi megjelenítések, az átnézeti térképek települései mellé és a várostérképekre helyezett kis épületrajzok a könyvnek. Gyakorlati haszna van az ismertetett látványosságok (túlnyomórészt épületek) egész könyvet átfogó és a térképeken is feltüntetett sorszámozásának. Ugyanezen sajátosságokkal ajánlják a megismerés, a felfedezés, az esztétikai élményszerzés lehetőségét a sorozat 1989 előtt és után megjelent könyvei (pl.: Tompos-Czellár, 1981; Németh, 2000).

Óriási változást jelentettek az 1989-1990-es térségbeli politikai, társadalmi, gazdasági események. A korábban korlátozott vagy tiltott utazást a határokat átívelő, tömeges szabad mozgás váltotta fel. Új lehetőségekhez jutott az útikönyvpiac is. A multikulturális térségekben több nyelven jelentek meg a kiadványok, az olvasók elvárásaihoz igazodva, ezekben hangsúlyosabb a saját kultúrához tartozó elemek, információk bemutatása. Heltmann és Servatius (1993) német nyelvű Erdély-útikönyvében nagyobb terjedelemben ismertetik a történeti Erdély szász kultúrához tartozó területeit. Az útvonalak településnevei három nyelven szerepelnek, megjelenítik minden település tengerszint feletti magasságát, első okleveles említését és a legújabb népességszámadatot. Történelmi, építészeti, művelődési, néprajzi értékeket ismertet, nem tartalmazza a turisztikai szolgáltatások leírását. 
Magyar nyelvű Erdély-útikönyvek egész sora jelent meg ebben az időszakban. A Cartographia kiadó sajátos arculatú sorozatában Erdély (Koszta Nagy, 1998), Máramaros, Partium (Koszta Nagy, 1999), majd egy több kiadást megért újabb Erdély (Elekes, 2004) -útkönyv. Előnyös forma, megfelelő méret, kiváló minőségü színes fényképek és térképek, szolgáltatói információk. A korlátozott terjedelem nagy mennyiségű történelmi, művelődési, földrajzi, néprajzi információt tartalmaz, de a desztinációk bővebb ismertetése szélesebb körű megismerést tenne lehetővé. A legutóbbi kiadásokban mondák, legendák, rövid magyarázó szövegrészek is szerepelnek, a megismerés, felfedezés eszközei között megjelent a szórakoztató elem. A magyar és román településnevek a tájékozódást és a beazonosítást segítik. A „három pont” rendszer a desztinációkat értékeli. A gyakorlati jelleget erősíti a Cartographia nagyméretű Erdély térképének 18 oldalra történő beillesztése. A kihajtható belső borítók is információhordozó szerepet kaptak.

Deák és László (2004) Székelyudvarhelyen megjelent útikalauzában új elem az 12 oldalas művészeti, művelődéstörténeti, történeti írások, versek, népdalszövegek és mondarészletek beillesztése. A hagyományostól eltérő kiadványukkal a szerzők egy piaci szegmenst, az irodalom iránt nyitott társadalmi réteget célozták meg. Az egy tömbbe beillesztett színes fényképek elkülönülő egységként jelennek meg, a könyv végén levő térképvázlatok a térbeli eligazodáshoz nyújtanak segítséget. A könyv végén irodalomjegyzék szerepel.

Saját tapasztalat, a helyszínen ellenőrzött információk alapján írta meg Sós és Farkas (2005) a több kiadást megért Erdély útikönyvet. A szerzők az előbbieknél másfélkétszer nagyobb terjedelemben ismertetik a desztinációkat a jellegzetes felépítésü, szerkezetű könyvben. A történelem, a művészet, építészet mellett hangsúlyosan jelenik meg a néprajz, a hagyományok, mondák világa. A települések ismertetése után a turisztikai szolgáltatások (szállás, evés-ivás, szórakozás, gyakorlati tudnivalók) bő ismertetésére kerül sor. A látványosságok beazonosítását, a tájékozódást több oldalas színes „fényképtömbök” és egyszerű térképek, térképvázlatok segítik.

Román nyelven a teljes országot bemutató útikönyvek jelentek meg. Pascaru és Andreescu (2007) könyvét angol, francia és román nyelven is megjelentették. Guide (2010) történelmi-néprajzi tájegységek jelentősebb településeit, elsősorban román építészeti, művelödési, történeti értékeit ismerteti. A szerző megfogalmazása szerint az olvasóval bejárják Máramaros festői falvait, Bukovina és Moldva templomait, az egyedi Duna Deltát, Dobrudzsa híres várait, Munténia szép kolostorait, majd a Kárpátokon túli szép és csendes Erdélyt. A kép- és térképanyag növeli a könyv értékét.

Juler (2010) munkája Románia leglátogatottabb turisztikai övezeteire összpontosít. Idő, igény és lehetőségekhez igazított útvonalakat ajánl, természeti, művészeti, művelődéstörténeti értékekre hívja fel a turista figyelmét. 
1990 után történeti-néprajzi régiók, megyék útikönyvei jelentek meg a térségben. Vofkori (1988) kétkötetes, 640, illetve 607 oldalas műve messze meghaladja az útikönyvek terjedelmét. Székelyföldi települések, településrészek komplex, nagyon részletes bemutatására vállalkozik. Tileagda és munkatársai (2011) az erdélyi Fehér megye idegenforgalmi értékeit ismertetik egy hagyományos felépítésü útikönyvben.

Megjelentek a piacon a sajátos igényekhez igazodó, egy érdeklődési kört kiszolgáló kiadványok. Ide sorolható pl. az erdélyi, partiumi, máramarosi és bánsági hegyi ösvényeket ismertető, a Túrázók Nagykönyve sorozatban megjelent nagyon jó minőségü, gazdagon illusztrált Erdély legszebb túraútvonalai című könyv (Szilágyi, 2011).

Napjaink útikönyvpiacának számos kiadványa az ételek, éttermek és szállodák, fesztiválok, sport- és szabadidős tevékenységek ismertetésére fekteti a hangsúlyt, a kikapcsolódás-, szórakozásközpontú élményszerző lehetőségek, desztinációk reklámszerü, „maximalizált formában” történő bemutatása válik elsődlegessé. Másodlagosak a kulturális programok és desztinációk, a tematikus programok.

\section{Összefoglalás, következtetések}

Az útikönyv többnyire olyan objektív információkat tartalmaz, amelyek ösztönzik az olvasót-utazót a kiválasztott desztináció megismerésére, megértésére, felfedezésére, az esztétikai élmény megvalósulására, elősegíti az utazás sikeres teljesítését. Az interdiszciplináris jellegü könyv fiziológiai, biztonsági, hovatartozási, esztétikai és önmegvalósítási szükségletek beteljesülését segíti elő (Maslow, 1970).

A XX. század elejére térségünkben kialakult az útikönyvek funkcióhoz igazodó szerkezete, felépítése, véglegesedtek tartalmi elemei.

Történelmi korszakok ideológiai hatása jelenik meg a szövegtartalmakban, fényképeken.

Az olvasó igényeihez igazodva, a multikulturális térségekben hangsúlyosabb a saját kultúrához tartozó elemek, információk bemutatása.

Sajátos kiadói arculattal jelennek meg az útikönyvsorozatok.

A nyomdatechnika, a fényképezés és a térképszerkesztés fejlödése nyomon követhető a kiadványok minőségi változásain.

A technikai fejlődés hozzájárult az útikönyvek minőségi, megjelenítési javulásához, később a technikai lehetőségek, az internet az útikönyvek versenytársává vált. Napjainkban kiegészítik az informatikai, technikai lehetőségeket és továbbra is az információszerzés forrásai, desztinációk bemutatását, ismertetését végzik. Ugyanakkor ismeretes, hogy az információtechnológia által kínált lehetőségek elérhetősége mindenütt nem biztosított.

A XX. századi útikönyvek gyakorlatias célokhoz igazodó, nagyobbrészt kulturálistudományos értékeket közvetítettek, megerősítették az utazó kulturális hátterét. 
A XX. század végére az útikönyvek egy másik típusa jelent meg, ahol a kikapcsolódás, a szórakozásközpontú, élményszerző lehetőségek kerülnek előtérbe. A mai útikönyv egyik feladata a piac igényeihez igazodó, megfelelő egyensúly megtalálása, megvalósítása, közvetítése.

Előnyös, ha egy ország, térség, város útikönyvét ott élő vagy az ismertetett területet „szülőföld- és anyanyelvi szinten” ismerő szerző írja. Ez esetben az olvasó az informatikai források által is biztosított gyakorlati információk, tudományos, művészeti ismeretek mellett a személyes élményeken is alapuló tapasztalatok szintézisét kapja. Ez színesebb, az általánostól, a globálistól eltérő, személyesebb esztétikai élmény megélését biztosítja az olvasó-utazó számára.

\section{Köszönetnyilvánítás}

A cikkben ismertetett kutatómunka az EFOP-3.6.1-16-2016-00011 jelü „Fiatalodó és Megújuló Egyetem - Innovatív Tudásváros - a Miskolci Egyetem intelligens szakosodást szolgáló intézményi fejlesztése" projekt részeként - a Széchenyi 2020 keretében - az Európai Unió támogatásával, az Európai Szociális Alap társfinanszírozásával valósult meg.

\section{Hivatkozott források}

[1.] Ádám L. - Belia Gy. - Csatári D. (1979): Románia. Panoráma, 679 o.

[2.] Buzzard, J. (2002): The Grand Tour and after (1660-1840). In: Hulme, P. - Youngs, T. (Eds.) The Cambridge Companion to Travel Writing. 48-50. p.

[3.] Cioculescu, S. (1967): România. Ghid turistic. București, Meridiane, 225 p.

[4.] De Beer, E. S. (1952) The development of the guide-book until the early nineteenth century. Journal of the British Archaeological Association, Vol. 3. 35-46. p.

[1.] Deák F. - László L. (2004): Erdély útikalauz. Székelyudvarhely, Erdélyi Gondolat Könyvkiadó, 363 o.

[2.] Elekes T. (2004): Erdély. Budapest, Cartographia, 264 o.

[3.] Gherghilas, A. (2014): Geografia Turismului. Metode de analiză în turism. Bucureşti, Editura Universitară, 356 p.

[4.] Györmei S. (1934): Az utazási kedv története. Budapest, Gergely R. Kiadása, $134 \mathrm{o}$.

[5.] Guide, I. (2010): Romania. Ghid touristic. Bucureşti, Aquila, 384 p.

[6.] Gyuricza L. (2008): A turizmus nemzetközi földrajza. Budapest-Pécs, Dialóg Campus Kiadó, 319 o. 
[7.] Heltmann, H. H. - Servatius, G. (1993): Reisehandbuch Siebenbürgen. Würzburg, Kraft, 503 p.

[8.] Juler, C. (2010): Romania. National Geographic Traveler - ghid touristic, National Geographic, 270 p.

[9.] Koszta Nagy I. (1998): Erdély. Budapest, Cartographia, 221 o.

[10.] Koszta Nagy I. (1999): Máramaros. Partium. Budapest, Cartographia, 160 o.

[11.] Lukács A. (2012): Műfajspecifikus megfeleltetési stratégiák az útikönyvek fordításában. [PhD-disszertáció] Budapest, ELTE BTK, 282 o.

[12.] Markos B. - Kolacsek A. (1961): Idegenforgalom. Budapest, Közgazdasági és Jogi Könyvkiadó.

[5.] Maslow, A. (1970): Motivation and personality. New York: Harper and Row.

[13.] Mason, P. (2017): Geography of tourism. Oxford, Goodfellow Publishers, $256 \mathrm{p}$.

[14.] Mátyás V. (1986): Utazások Erdélyben. Negyedik, javított kiadás, Budapest, Panoráma, 280 o.

[15.] Michalkó G. - Rátz T. - Lontai-Szilágyi Zs. (2018): Irány a horizont! Az online navigáció utazási kockázatai. Universitas Budapestiensis de „Metropolitan", Annales Tom. 50. 10, pp 3-13.

[16.] Michalkó G. (2007): Magyarország modern turizmusföldrajza. BudapestPécs, Dialóg Campus Kiadó, 319 p.

[17.] Monmarché, M. (1933): Roumanie. Bulgarie. Turquie. Paris, Librairie Hachette, 702 p.

[18.] Murgu, M. (1967): Braşov. Bucureşti, Meridiane, 47 p.

[19.] Nedelcu, A. (2011): Geografia turismului. Bucureşti, Editura Universitară, $287 \mathrm{p}$.

[20.] Németh A. (2000): Kárpátalja. 4. kiadás, Budapest, Panoráma, 162 o. (Panoráma „mini” útikönyvek)

[21.] Orosz F. (1933): Cluj-Kolozsvár kalauz. Kolozsvár, Erdélyi Kárpát Egyesület, 172 o.

[22.] Pascaru, M. - Andreescu F. (2007): Romania. Ghid touristic. București, România, Ad libri, 96 p.

[23.] Possewitz T. (1909): A Szepesség utazási kézikönyve. II. A Szepesiközéphegység. Budapest, Pátria idod. váll. és nyomdai R.T., 176 o.

[24.] Sós J - Farkas Z. (2005): Erdély útikönyv. Frissített és bővített kiadás. Budapest, Jel-kép Bt., 454 o.

[25.] Szilágyi P. P. (2011): Erdély legszebb túraútvonalai. Budapest, Totem Kiadó, 528 o.

[26.] Ürögdi Gy. (1979): Hogyan utaztak a régi rómaiak? Budapest, Panoráma, 213 o. 
[27.] Tileagda, F.-R. si colab. (2011): Judetul Alba. Ghid turistic. Buzau, Vega Prod, $324 \mathrm{p}$.

[28.] Tompos E. - Czellár K. (1981): Moldvai utazások. Második, javított kiadás. Budapest, Panoráma, 160 o.

[29.] Towner, J. (2000): Guidebook. In: Jafari, J. (Ed.) 2000. Encyclopaedia of Tourism. London, Routledge. 267-269. p.

[30.] Vofkori L. (1998): Székelyföld útikönyve. I-II. Budapest, Cartographia, 640 o., 607 o.

\section{Szerző:}

Dr. Elekes Tibor

egyetemi docens

Miskolci Egyetem, MFK,

Földrajz-Geoinformatika Intézet

ecoeti@uni-miskolc.hu 